University of Nebraska - Lincoln

DigitalCommons@University of Nebraska - Lincoln

Faculty Papers and Publications in Animal

Science

Animal Science Department

July 1984

\title{
SOW PRODUCTIVITY COMPARISONS FOR FOUR BREEDS OF SWINE: PUREBRED AND CROSSBRED LITTERS
}

\author{
H. R. Gaugler \\ Oklahoma State University, Stillwater \\ D. S. Buchanan \\ Oklahoma State University, Stillwater \\ R. L. Hintz \\ Oklahoma State University, Stillwater \\ R. K. Johnson \\ Oklahoma State University, Stillwater, rjohnson5@unl.edu
}

Follow this and additional works at: https://digitalcommons.unl.edu/animalscifacpub

Part of the Animal Sciences Commons

Gaugler, H. R.; Buchanan, D. S.; Hintz, R. L.; and Johnson, R. K., "SOW PRODUCTIVITY COMPARISONS FOR FOUR BREEDS OF SWINE: PUREBRED AND CROSSBRED LITTERS" (1984). Faculty Papers and

Publications in Animal Science. 83.

https://digitalcommons.unl.edu/animalscifacpub/83

This Article is brought to you for free and open access by the Animal Science Department at DigitalCommons@University of Nebraska - Lincoln. It has been accepted for inclusion in Faculty Papers and Publications in Animal Science by an authorized administrator of DigitalCommons@University of Nebraska - Lincoln. 


\title{
SOW PRODUCTIVITY COMPARISONS FOR FOUR BREEDS OF SWINE: PUREBRED AND CROSSBRED LITTERS ${ }^{1}$
}

\author{
H. R. Gaugler ${ }^{2}$, D. S. Buchanan ${ }^{3}$, R. L. Hintz ${ }^{3}$ and R. K. Johnson ${ }^{4}$ \\ Oklahoma State University, Stillwater 74078
}

\section{Summary}

Data were collected from 366 litters produced in a four-breed (Duroc, Yorkshire, Spotted and Landrace) diallel mating system. Purebred and crossbred litters were farrowed during five consecutive (fall and spring) farrowing seasons (fall 1976 through fall 1978). Litrers were produced by randomly mating boars of each breed to at least one female of each breed. Litter size and weight at birth, litter size and weight at $42 \mathrm{~d}$ and pig survival to $42 \mathrm{~d}$ were analyzed. There were significant parity effects for all traits except survival rate, and significant year and season effects for litter size at birth and $42 \mathrm{~d}$ and litter weight at $42 \mathrm{~d}$. Large breed of dam differences were detected for most sow productivity traits. Litters from Spotted females were smaller and lighter in weight. Landrace females were most productive in terms of litter weight at weaning and proportion of their pigs raised from birth to weaning. Breed of sire differences were not significant for any trait. Significant heterosis estimates were obtained for litter size and weight at weaning and for survival rate. Crossbred litters had .79 more pigs, were $11.72 \mathrm{~kg}$ heavier at weaning and had a $5.56 \%$ greater survival rate than the average of all purebreds.

(Key Words: Swine, Crossbreeding, Sow Productivity.)

\footnotetext{
${ }^{1}$ Published as Paper No. 4290 Journal Series, Oklahoma Agr. Exp. Sta., Stillwater and a contribution from Regional Project NC-103, Genetic Improvement of Efficiency in the Production of Quality Pork.

${ }^{2}$ Present address: Lemmon, SD 57638.

${ }^{3}$ Anim. Sci. Dept. Oklahoma State Univ., Stillwater.

${ }^{4}$ Present address: Anim. Sci. Dept., Univ. of Nebraska, Lincoln 68583 .

Received March 16, 1983.

Accepted March 30, 1984.
}

\section{Introduction}

Sow productivity has important influences on efficiency in a swine enterprise. It is a composite of several traits including ovulation rate, conception rate, embryo survival and the sow's ability to farrow live pigs. In addition, the sow contributes to her litter's survival and growth through direct genetic effects and the environment she provides.

Measurements of sow productivity are generally lowly heritable (Young et al., 1978) but theoretically should respond well to crossbreeding. There has been much research on crossbreeding effects on sow productivity (Johnson, 1980). There remains a need to further evaluate the potential contributions of additional breeds such as the Spotted and the Landrace.

The objectives of this experiment were to evaluate heterosis for sow productivity and to examine the usefulness of the Duroc, Yorkshire, Landrace and Spotted breeds in purebred and two-breed cross matings.

\section{Materials and Methods}

Litters produced in a four breed diallel mating system involving the Duroc, Spotted, Yorkshire and Landrace breeds were born during five consecutive (fall, spring) farrowing seasons beginning in the fall of 1976. During each season, boars were mated at random to at least one female of each breed group. A total of 366 purebred and crossbred litters from 170 females and 41 boars were produced and analyzed for litter size and weight at birth, but only 345 litters were utilized in the analyses of weaning traits. Litters were discarded for analysis at weaning if there was serious illness in the sow. There were between 20 and 29 litters for each breed combination with reciprocal crosses considered as different combinations. Females were allowed to farrow more than once, so parity was divided into three categories: first-parity gilts, second-parity sows and those sows with more than two litters. The number of 941

JOURNAL OF ANIMAL SCIENCE, Vol. 59, No. 4, 1984 
litters produced in each parity group was not uniform for the different breed group combinations.

In the spring of 1976, 25 gilts and four boars from both the Landrace and Spotted breeds were purchased from breeders to establish herds. Landrace gilts came from two herds and Landrace boars were from four other herds. Spotted boars and gilts originated in nine different herds. Duroc and Yorkshire herds had been maintained at the University for several years with a broad genetic base by semiannual introduction of at least one new boar. In order to sample and maintain as broad a genetic base as practical, at least one boar of each breed was replaced each season. Purebred females of each breed were maintained by within herd selection of replacement gilts. Selection was based primarily upon an index of growth rate and backfat thickness (Hubbard, 1976).

Husbandry and Data Collection. Females were hand mated during an 8-wk breeding period. Gestating females were maintained in pasture lots and hand-fed a daily diet of 1.8 to $2.2 \mathrm{~kg}$ of a $15 \%$ crude protein corn (IFN 4-02-931) or sorghum grain (IFN 4-04-383) based diet. Litters were farrowed in a central confinement building. Spring litters were farrowed in March and April and fall litters were farrowed in September and October. Individual pig weights were recorded on all fully formed piglets within $12 \mathrm{~h}$ of birth. Litters, and their dams, were moved at 1 to 2 wk of age to pasture lots with three to four litters/lot or to an open-front confinement building with one litter/pen. Litters were provided access to creep feed between 2 and 3 wk of age and were weaned at approximately 6 wk of age. Individual pig weights were recorded at weaning and adjusted to $42 \mathrm{~d}$ using an adjustment factor developed at the Oklahoma station. Traits included in these analyses were litter size at birth, litter weight at birth, litter size at weaning, litter weight at weaning and percentage survival from birth to weaning.

Data Analyses. The following linear model was assumed for all traits analyzed:

$$
y=x \beta+Z_{1} s+Z_{2} d+e,
$$

where $\mathbf{y}$ is an observation vector; $\mathbf{X}$ is a known design matrix of fixed effects; $\beta$ is an unknown vector of fixed effects (all levels of breed of sire, breed of dam, parity, year, season, year $x$ season, parity $x$ season, breed of dam $x$ season, breed of dam $\times$ parity, breed of sire $\times$ breed of dam and a common constant $\mu$ ); $Z_{1}$ is a known design matrix for sires; $Z_{2}$ is a known design matrix for the breed of dam $x$ sire within breed of sire interaction; $s$ is a random vector of the sire effects; $d$ is a random vector of the breed of dam $X$ sire within breed of sire interaction effects; $e$ is a random vector of residual effects, and $s, d$ and $e$ are mutually uncorrelated having multivariate distributions with means zero and nonsingular variance-covariance matrices $\mathrm{IV}_{\mathrm{S}}$, $I_{d}$ and $I V_{e}$, respectively. It was also assumed that there were no correlations among the elements of $\mathbf{s}$ and $\mathbf{d}$. There were some sows that were used in more than one farrowing season, so that the elements of $d$ are not truly uncorrelated. This may result in some downward bias in standard errors associated with fixed effects. This model was chosen after preliminary analyses revealed that other two- and three-way interactions were not significant $(\mathrm{P}>.20)$.

Henderson's Method 3 (Henderson, 1953) was utilized to obtain estimates of the following variance components for each of the five traits:

$$
\begin{aligned}
V_{s}= & \text { sire component of variance, } \\
v_{d}= & \text { breed of dam } \times \text { sire within breed of } \\
& \text { sire interaction component of vari- } \\
& \text { ance and } \\
V_{e}= & \text { residual component of variance. }
\end{aligned}
$$

If variance ratios are known for the class of linear models assumed and assumptions made, the solutions $\hat{\beta}$ are generalized least-squares estimates of the fixed effects (Henderson et al., 1959; Henderson, 1973), and solutions $\hat{s}$ and $\hat{d}$ are best linear unbiased predictors of the random effects (Henderson, 1963, 1973). Although variance ratios are never really known, estimates can be obtained from heritability and variance component estimates. Few estimates were available in the literature. Therefore, estimates obtained from the data were used. As a result, these estimates of the fixed effects only approach being best linear unbiased estimates as the estimates of variance components approach the true value.

Specific linear contrasts among generalized least-squares means were calculated for each trait in a manner analagous to that of Harvey (1977). Linear contrasts were constructed to provide information of interest without regard 
to orthogonality or linear independence, and more linear contrasts were made than there were degrees of freedom. Differences were tested utilizing the t-test (LSD; Steel and Torrie, 1960).

\section{Results and Discussion}

Tests of Estimable Functions for Sow Productivity Traits. The linear model for the sow productivity traits included environmental factors such as year and season, which were not significant for either litter weight at birth or survival rate, and parity which was important $(\mathrm{P}<.05)$ for all traits except percentage survival (table 1). In general, fall-born litters and litters from first-parity gilts tended to be smaller and lighter in weight at both birth and weaning. Breed of sire and the interaction of breed of sire with breed of dam were not significant factors affecting any trait, although the interaction term approached significance $(\mathrm{P}<.10)$ for both litter weight at weaning and percentage survival. The breed of dam effect was important $(\mathrm{P}<.05)$ for all traits except litter size at weaning. The generalized leastsquares means for breed of sire by breed of dam combinations are shown in table 2.

Comparisons Among Breeds of Dam. Differences among breeds in maternal performance were significant for most traits associated with sow productivity (table 3 ). Yorkshire, Landrace and Duroc females farrowed significantly larger litters than did Spotted dams $(1.95 \pm .54,1.29$ \pm .50 and $1.62 \pm .53$ more pigs, respectively). However, litter weights at birth were significantly greater for Duroc and Landrace females than for litters from Yorkshire and Spotted females. This indicates that Yorkshire dams farrowed lighter weight pigs which may have contributed to the higher $(P<.10)$ preweaning mortality rate observed in litters from Yorkshire females. Yorkshire dams had the largest litters at $42 \mathrm{~d}$, but no significant differences among dam breeds were detected. At 42 d, litter weight was significantly greater for Landrace females than for Spotted (11.24 \pm $4.61 \mathrm{~kg})$ and Duroc $(9.68 \pm 4.94 \mathrm{~kg})$ females, and were $8.15 \pm 5.16 \mathrm{~kg}$ heavier than litters from Yorkshire females. Contrary to results reported by Fahmy et al. (1971), these data indicated that litters produced by Yorkshire females have higher preweaning mortality rates than do the other breeds involved, although litter size is still larger at both birth and weaning. These data indicate that Landrace females

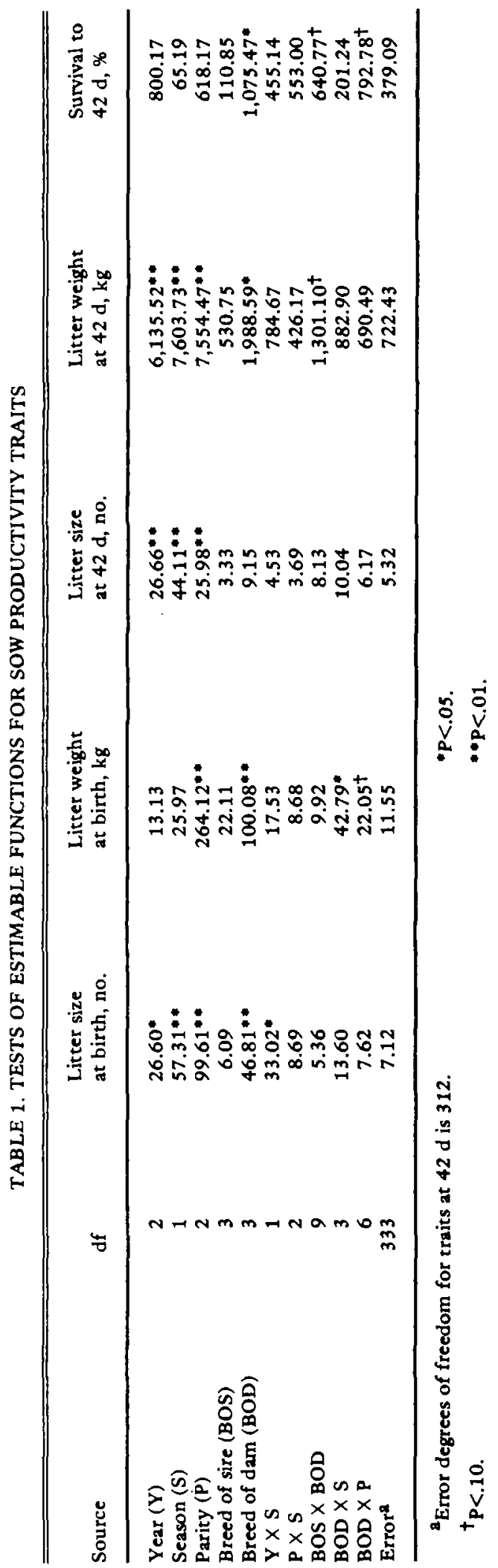


TABLE 2. PUREBRED AND RECIPROCAL CROSS GENERALIZED LEAST-SQUARES MEANS FOR SOW PRODUCTIVITY TRAITS

\begin{tabular}{|c|c|c|c|c|c|c|}
\hline Item & No.a & $\begin{array}{l}\text { Litter size } \\
\text { at birth, no. }\end{array}$ & $\begin{array}{l}\text { Litter weight } \\
\text { at birth, kg }\end{array}$ & $\begin{array}{l}\text { Litter size } \\
\text { at } 42 \mathrm{~d} \text {, no. }\end{array}$ & $\begin{array}{l}\text { Litter weight } \\
\text { at } 42 \mathrm{~d}, \mathrm{~kg}\end{array}$ & $\begin{array}{l}\text { Survival to } \\
42 \mathrm{~d}, \%\end{array}$ \\
\hline $\mathrm{D} \times \mathrm{D}^{\mathrm{b}}$ & 28 & 10.44 & 14.65 & 6.29 & 70.30 & 67.80 \\
\hline $\mathrm{D} \times \mathrm{S}$ & 23 & 9.44 & 13.39 & 7.37 & 85.51 & 79.52 \\
\hline $\mathbf{D} \times \mathbf{Y}$ & 21 & 11.41 & 13.30 & 8.06 & 87.41 & 68.35 \\
\hline$D \times L$ & 22 & 10.06 & 15.58 & 8.09 & 97.99 & 83.71 \\
\hline $\mathbf{S} \times \cdot \mathbf{D}$ & 22 & 11.62 & 16.80 & 8.57 & 94.24 & 78.34 \\
\hline $\mathbf{S} \times \mathbf{S}$ & 25 & 9.40 & 12.80 & 6.85 & 74.26 & 74.25 \\
\hline $\mathbf{S} \times \mathbf{Y}$ & 22 & 12.40 & 15.56 & 9.31 & 97.90 & 74.45 \\
\hline $\mathbf{S} \times \mathbf{L}$ & 20 & 11.43 & 16.81 & 7.60 & 93.72 & 70.55 \\
\hline $\mathbf{Y} \times \mathbf{D}$ & 24 & 10.32 & 14.26 & 7.09 & 79.18 & 72.04 \\
\hline $\mathbf{Y} \times \mathbf{S}$ & 20 & 9.57 & 12.80 & 7.29 & 83.85 & 76.69 \\
\hline $\mathbf{Y} \times \mathbf{Y}$ & 23 & 11.52 & 13.34 & 7.25 & 73.53 & 64.21 \\
\hline $\mathbf{Y} \times \mathbf{L}$ & 25 & 10.43 & 14.27 & 8.18 & 90.59 & 81.69 \\
\hline$L \times D$ & 20 & 11.60 & 16,18 & 8.24 & 90.63 & 72.12 \\
\hline $\mathrm{L} \times \mathrm{S}$ & 22 & 9.10 & 12.28 & 7.25 & 83.50 & 79.96 \\
\hline$L \times Y$ & 20 & 9.97 & 11.79 & 7.31 & 80.66 & 79.35 \\
\hline $\mathbf{L} \times \mathbf{L}$ & 29 & 10.74 & 14.61 & 7.88 & 89.79 & 76.97 \\
\hline $\mathrm{SEC}$ & & $.73-.81$ & $1.00-1.10$ & $.65-.72$ & $6.64-8.00$ & $4.04-5.02$ \\
\hline
\end{tabular}

${ }^{a}$ One or two litters from each breed group were not included in the analyses of the traits at 42 days.

${ }^{b} \mathrm{D}=$ Duroc, $\mathrm{S}=$ Spotted, $\mathrm{Y}=$ Yorkshire, $\mathrm{L}=$ Landrace; the first letter is breed of sire, the second letter is the breed of dam.

${ }^{c}$ Range of standard errors among the breed combinations for each trait.

were most effective in keeping their pigs alive and supplying adequate nutrition for them to grow, although creep feed was available.

Comparisons Among Purebreds. There were few significant differences among purebreds for sow productivity traits (table 4). Purebred Landrace litters were smaller at birth $(.78 \pm$ 1.05) but larger at weaning $(.63 \pm .93)$ than Yorkshire litters due to a significantly greater survival rate $(12.77 \pm 5.93 \%)$. Landrace litters were larger at birth and weaning than purebred Duroc and Spotted litters. Consequently, Landrace litters were heavier at $42 \mathrm{~d}$ than Duroc $(19.49 \pm 9.25 \mathrm{~kg})$, Yorkshire (16.25 \pm $9.59 \mathrm{~kg})$ and Spotted $(15.53 \pm 9.21 \mathrm{~kg})$ litters. In contrast, Smith and McLaren (1967) found Duroc litters were larger at all ages than Landrace litters. This difference was larger at wean-

TABLE 3. COMPARISONS AMONG BREEDS OF DAM FOR SOW PRODUCTIVITY TRAITS

\begin{tabular}{lccccc}
\hline Contrasts & $\begin{array}{l}\text { Litter size } \\
\text { at birth, no. }\end{array}$ & $\begin{array}{l}\text { Litter weight } \\
\text { at birth, kg }\end{array}$ & $\begin{array}{l}\text { Litter size } \\
\text { at 42 d, no. }\end{array}$ & $\begin{array}{l}\text { Litter weight } \\
\text { at 42 d, kg }\end{array}$ & $\begin{array}{l}\text { Survival to } \\
\mathbf{4 2} \mathrm{d}, \%\end{array}$ \\
\hline $\mathrm{D}-\mathrm{S}$ & $1.62 \pm .53^{* *}$ & $2.65 \pm .73^{* *}$ & $.36 \pm .47$ & $1.56 \pm 4.96$ & $-5.03 \pm 3.27$ \\
$\mathrm{D}-\mathrm{Y}$ & $-.33 \pm .54$ & $1.98 \pm .73^{* *}$ & $-.44 \pm .48$ & $-1.54 \pm 5.06$ & $.98 \pm 3.35$ \\
$\mathrm{D}-\mathrm{L}$ & $.33 \pm .53$ & $.16 \pm .72$ & $-.39 \pm .47$ & $-9.68 \pm 4.94^{*}$ & $-5.56 \pm 3.26^{\dagger}$ \\
$\mathrm{S}-\mathrm{Y}$ & $-1.95 \pm .54^{* *}$ & $-.68 \pm .74$ & $-.80 \pm .49$ & $-3.10 \pm 5.16$ & $6.02 \pm 3.42^{\dagger}$ \\
S-L & $-1.29 \pm .50^{* *}$ & $-2.49 \pm .69^{* *}$ & $-.75 \pm .44$ & $-11.24 \pm 4.61^{*}$ & $-.52 \pm 3.01$ \\
Y - L & $.66 \pm .54$ & $-1.82 \pm .73^{*}$ & $.05 \pm .49$ & $-8.15 \pm 5.16$ & $-6.54 \pm 3.42^{\dagger}$ \\
\hline
\end{tabular}

\footnotetext{
${ }^{a} \mathrm{D}=$ Duroc, $\mathrm{S}=$ Spotted, $\mathrm{Y}=$ Yorkshire, $\mathrm{L}=$ Landrace.

${ }^{\dagger} \mathrm{P}<\mathrm{10}$.

* $P<.05$.

** $\mathrm{P}<.01$.
} 

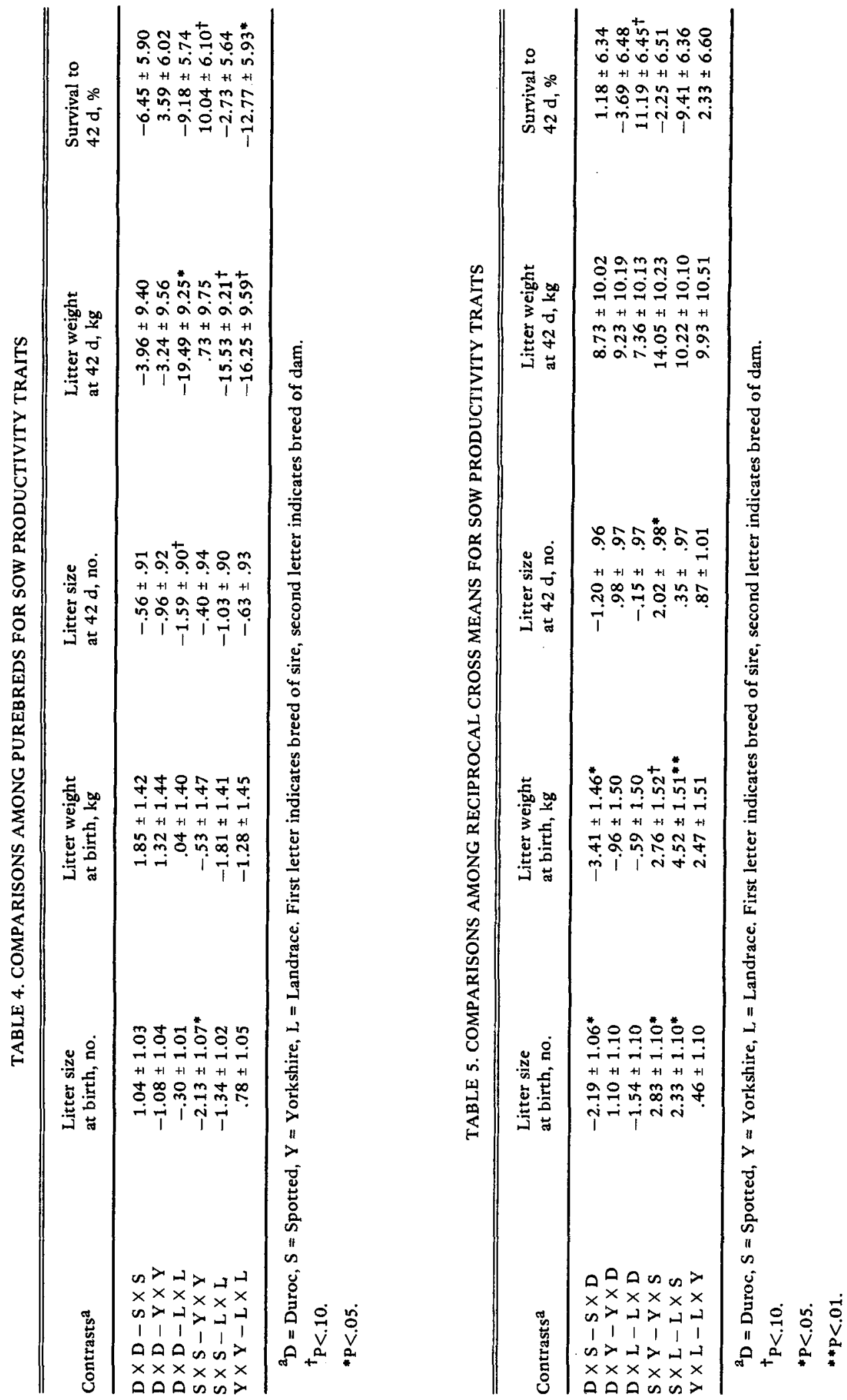
ing than at birth due to a greater survival rate of Duroc pigs; consequently litter weight was also greater at weaning for Duroc litters. Yorkshire litters were larger at birth than litters of the other three breeds and Spotted litters were the smallest. At weaning, differences in litter size between Yorkshire litters and Spotted or Duroc litters were reduced, which was also due to the lower survival rate of the Yorkshire pigs. Duroc litters were larger and heavier at birth than Spotted litters, while they were smaller but heavier than Yorkshire and Landrace litters. At weaning, Duroc litters were smaller and lighter in weight than any of the other three types of purebred litters.

Comparison of Reciprocal Cross Means. Because reciprocal crosses would be expected to contain similar gene combinations, any differences between reciprocals would be expected to be due to maternal genetic differences or to an interaction of the maternal genetic effects and the direct genetic effects. A comparison among reciprocal crosses for sow productivity traits (table 5) indicates that significant differences did exist for all traits except litter weight at weaning but not for all breed combinations. The largest difference in litter size at birth $(2.83 \pm 1.10$ pigs $)$ and weaning $(2.02 \pm .98$ pigs) was exhibited by Spotted-Yorkshire reciprocal crosses and the largest difference in litter weight at birth (4.52 $\pm 1.51 \mathrm{~kg}$ ) involved crosses of Spotted and Landrace. The largest difference for survival rate $(\mathrm{P}<.10)$ involved Duroc-Landrace reciprocal crosses. Large differences between recipro- cal crosses would indicate that the advantages obtained from crossbreeding are dependent upon the mating structure utilized.

Heterosis Estimates. Reciprocal cross means were combined for the estimation of heterosis (table 6). Most heterosis estimates were positive for all traits studied. However, Duroc-Yorkshire and Yorkshire-Landrace cross litters at birth were not as large or as heavy as the average of the respective purebreds. All other heterosis estimates for these two traits were positive, although none was significant. Heterosis for traits associated with weaning were positive. The overall differences of $.79 \pm .35$ pigs/litter at weaning $(\mathrm{P}<.05), 11.72 \pm 3.63 \mathrm{~kg} / \mathrm{litter}(\mathrm{P}<.01)$ and $5.56 \pm 2.36$ percentage units greater survival rates $(P<.05)$ of crossbred litters over the average of all purebred litters are in agreement with most research (Smith and McLaren, 1967; Young et al., 1976; Sellier, 1976; Johnson, 1980). Specific comparisons indicate both Spotted-Duroc and Spotted-Yorkshire crosses exhibit substantial amounts of heterosis for litter size $(\mathrm{P}<.05)$ and weight $(\mathrm{P}<.01)$ at weaning. Yorkshire-Landrace crosses yielded $9.93 \pm 4.25 \%$ greater survival rates and consequently, heterosis for litter size increased from $-.93 \pm .70 \mathrm{pigs} / \mathrm{litter}$ at birth to $.18 \pm .63$ pigs/litter at weaning. In contrast, SpottedLandrace crosses had a small negative heterosis estimate and, therefore, the crossbred advantage in litter size was reduced from birth to weaning. The overall heterosis estimates expressed as a percentage of the purebred mean are similar to those presented by Johnson

TABLE 6. HETEROSIS ESTIMATES ${ }^{a}$ FOR SOW PRODUCTIVITY TRAITS

\begin{tabular}{lccccc}
\hline $\begin{array}{l}\text { Reciprocal } \\
\text { crosses }\end{array}$ & $\begin{array}{l}\text { Litter size at } \\
\text { birth, no. }\end{array}$ & $\begin{array}{l}\text { Litter weight } \\
\text { at birth, kg }\end{array}$ & $\begin{array}{l}\text { Litter size } \\
\text { at } 42 \mathrm{~d}, \text { no. }\end{array}$ & $\begin{array}{l}\text { Litter weight } \\
\text { at } 42 \mathrm{~d}, \mathrm{~kg}\end{array}$ & $\begin{array}{l}\text { Survival to } \\
42 \mathrm{~d}, \%\end{array}$ \\
\hline $\mathrm{D}-\mathrm{S}$ & $.61 \pm .68$ & $1.37 \pm .93$ & $1.39 \pm .61^{*}$ & $17.60 \pm 6.36^{* *}$ & $7.91 \pm 4.17^{*}$ \\
$\mathrm{D}-\mathrm{Y}$ & $-.11 \pm .69$ & $-.21 \pm .95$ & $.80 \pm .61$ & $10.88 \pm 6.36^{\dagger}$ & $4.19 \pm 4.17$ \\
$\mathrm{D}-\mathrm{L}$ & $.24 \pm .69$ & $1.25 \pm .94$ & $1.08 \pm .61^{\dagger}$ & $14.27 \pm 6.36^{*}$ & $5.33 \pm 4.16$ \\
S - Y & $.53 \pm .72$ & $1.11 \pm .98$ & $1.25 \pm .63^{*}$ & $16.98 \pm 6.58^{* *}$ & $6.34 \pm 4.31$ \\
S-L & $.19 \pm .70$ & $.84 \pm .96$ & $.07 \pm .62$ & $6.59 \pm 6.42$ & $-.36 \pm 4.18$ \\
Y - L & $-.93 \pm .70$ & $-.95 \pm .97$ & $.18 \pm .63$ & $3.97 \pm 6.55$ & $9.93 \pm 4.25^{*}$ \\
Overall & $.09 \pm .40$ & $.57 \pm .54$ & $.79 \pm .35^{*}$ & $11.72 \pm 3.63^{* *}$ & $5.56 \pm 2.36^{*}$ \\
\hline
\end{tabular}

${ }^{a}$ Heterosis expressed in actual units, as a deviation from the respective purebred mean.

$\mathrm{b}_{\mathrm{D}}=$ Duroc, $\mathrm{S}=$ Spotted, $\mathrm{Y}=$ Yorkshire, $\mathrm{L}=$ Landrace.

$\dagger_{\mathrm{P}}<\mathrm{10}$.

$* \mathrm{P}<.05$.

$* * \mathrm{P}<.01$ 
(1980) and Sellier (1976), while individual estimates were quite variable.

These data indicate that, of the four breeds evaluated, Yorkshires were more productive in terms of litter size at birth and weaning while Landrace females were more productive in terms of litter weight at weaning and the ability to keep their pigs alive to weaning. Breed of sire effects were not significant for litter size traits, litter weight at weaning or survival rate. Heterosis was detected for litter weight at $42 \mathrm{~d}$ and for pig survival rate.

\section{Literature Cited}

Fahmy, M. H., C. S. Bernard and W. B. Holtman. 1971. Crossbreeding swine: Reproductive performance of seven breeds of sows bred to produce crossbred progeny. Can. J. Anim. Sci. $51: 361$.

Harvey, W. R. 1977. User's Guide to LSML76. Ohio State Univ., Columbus.

Henderson, C. R. 1953. Estimation of variance and covariance components. Biometrics 9:226.

Henderson, C. R. 1963. Selection index and expected advance. In: W, D. Hanson and H. F. Robison (Ed.) Statistical Genetics and Plant Breeding. Pub. 982. pp 141-163. National Academy of Sciences - National Research Council, Washing- ton, DC.

Henderson, C. R. 1973. Sire evaluation and genetic trends. Proc. of the Anim. Breeding and Genetics Symp. in Honor of Dr. J. L. Lush. p 10. Amer. Soc. Anim. Sci. - Amer. Dairy Sci. Assoc., Champaign, II.

Henderson, C. R., O. Kempthorne, S. R. Searle and C. M. von Krosigk. 1959. The estimation of environmental trends from records subject to culling. Biometrics 15:192.

Hubbard, D. D. 1976. Guidelines for uniform swine improvement programs. Extension Service. USDA Program Aid 1157.

Johnson, R. K. 1980 . Heterosis and breed effects in swine. North Central Regional Publication 262.

Sellier, P. 1976. The basis of cross breeding in pigs; A review. Livestock Prod. Sci. 3:203.

Smith, H. J. and J. B. McLaren. 1967. Performance of breeds and breed crosses of swine. Tennessee Agr. Exp. Sta. Bull. 434.

Steel, R.G.D. and J. H. Torrie. 1960. Principles and Procedures of Statistics. McGraw-Hill Book Co., New York.

Young, L. D., R. K. Johnson and I. T. Omtvedt. 1976. Reproductive performance of swine bred to produce purebred and two-bred cross litters. J. Anim. Sci. 42:1133.

Young, L. D., R. A. Pumfrey, P. J. Cunningham and D. R. Zimmerman. 1978. Heritabilities and genetic and phenotypic correlations for prebreeding traits, reproductive traits and principle components. J. Anim. Sci. 46:937. 